of several initiatives in cardiac surgery, and we congratulate the authors on their important initiative to reduce this burden.

\footnotetext{
References

1. Wojnarski CM, Elgudin Y, Rubelowsky JJ, Wilson BM, Donskey CJ, Cmolik BL. Emerging trends in mediastinitis: National Veterans Health Administration experience with methicillin-resistant Staphylococcus aureus prevention. J Thorac Cardiovasc Surg. 2021;162:1125-30.e1

2. Abu-Omar Y, Kocher GJ, Bosco P, Barbero C, Waller D, Gudbjartsson T, et al. European Association for Cardio-Thoracic Surgery expert consensus statement on the prevention and management of mediastinitis. Eur J Cardiothorac Surg. 2017;51:10-29.

3. Engelman R, Shahian D, Shemin R, Guy TS, Bratzler D, Edwards F, et al. The Society of Thoracic Surgeons practice guideline series: antibiotic prophylaxis in cardiac surgery, part II: antibiotic choice. Ann Thorac Surg. 2007;83:1569-76.

4. Lazar HL, Salm TV, Engelman R, Orgill D, Gordon S. Prevention and management of sternal wound infections. J Thorac Cardiovasc Surg. 2016;152:962-72.
}

5. Morisaki A, Hosono M, Sasaki Y, Hirai H, Sakaguchi M, Nakahira A, et al. Evaluation of risk factors for hospital mortality and current treatment for poststernotomy mediastinitis. Gen Thorac Cardiovasc Surg. 2011;59:261-7.

6. Tom TS, Kruse MW, Reichman RT. Update: methicillin-resistant Staphylococcus aureus screening and decolonization in cardiac surgery. Ann Thorac Surg. 2009; 88:695-702.

7. Dodds Ashley ES, Carroll DN, Engemann JJ, Harris AD, Fowler VG Jr, Sexton DJ, et al. Risk factors for postoperative mediastinitis due to methicillin-resistant Staphylococcus aureus. Clin Infect Dis. 2004;38:1555-60.

8. Miyahara K, Matsuura A, Takemura H, Mizutani S, Saito S, Toyama M. Implementation of bundled interventions greatly decreases deep sternal wound infection following cardiovascular surgery. J Thorac Cardiovasc Surg. 2014; 148:2381-8.

9. Schweizer M, Perencevich E, McDanel J, Carson J, Formanek M, Hafner J, et al. Effectiveness of a bundled intervention of decolonization and prophylaxis to decrease Gram positive surgical site infections after cardiac or orthopedic surgery: systematic review and meta-analysis. BMJ. 2013;346:f2743.
See Article page 1125 .

\section{Commentary: Mediastinitis: Know the perps - keep the lights on and adapt strategy to asymptotically approach the Centers for Medicare and Medicaid Services "never-event" status}

\section{James B. McClurken, MD}

Wojnarski and colleagues ${ }^{1}$ have superbly analyzed the Veterans Affairs (VA) Healthcare System national methicillin-resistant Staphylococcus aureus (MRSA) prevention initiative launched in 2007 as it pertained to MRSA mediastinitis in isolated coronary artery bypass procedures performed at 83 VA hospitals. For 45,323 patients, the incidence of mediastinitis was $0.78 \%$; remarkably, the rate was $\sim$ flat throughout the January 2006 to December 2015 review period and throughout the system. In total, $75 \%$ were Gram (+), and MRSA was reduced as pathogen for mediastinitis to $16 \%$ of cases within the $70 \%$ Staphylococcus species. Methicillin-sensitive $S$ aureus was

From the Reif Heart Institute, Woodall Heart and Vascular Center, Doylestown Hospital, Doylestown, Pa.

Disclosures: Author has nothing to disclose with regard to commercial support.

Received for publication March 26, 2020; revisions received March 26, 2020; accepted for publication March 26, 2020; available ahead of print April 10, 2020. Address for reprints: James B. McClurken, MD, Doylestown Hospital, 599 W State St, Suite 207, Doylestown, PA 18901 (E-mail: jmcclurken@dh.org).

J Thorac Cardiovasc Surg 2021;162:1132-3

$0022-5223 / \$ 36.00$

Copyright (c) 2020 by The American Association for Thoracic Surgery

http://dx.doi.org/10.1016/j.jtcvs.2020.03.090
Check for updates

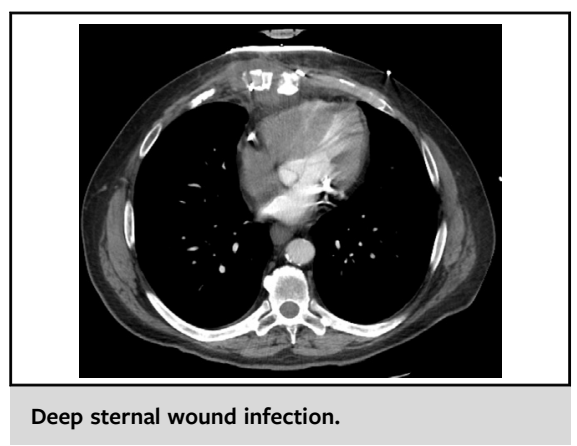

CENTRAL MESSAGE

With $<1 \%$ for mediastinitis, media-

stinitis "never-event" status as stipulated by CMS warrants revisiting.

the single most prevalent organism at $43 \%$. Gram (-) prevalence was $24.5 \%$. The rate of MRSA mediastinitis did decline significantly over 10 -year period under review. Average time to manifestation of mediastinitis was 22 days overall with 15 days for Gram (-) and 25 days for Gram (+). Although 30-day mortality was unaffected by mediastinitis, survival long-term (median 4.6 years, range 0-10 years) after mediastinitis was associated with $46 \%$ increased risk of death.

The authors' strategy for MRSA reduction included recognized Society of Thoracic Surgeons Practice Guidelines: firstgeneration cephalosporin, active surveillance cultures on admission, contact isolation for patients colonized or with infection, and MRSA prophylaxis in high-risk patients. Acknowledged as a key element was institutional "cultural transformation through provider education." Improved efforts 
targeting MSSA and Gram (-) organisms are fully warranted as suggested by the authors. Success as demonstrated in the VA Healthcare System was both "top-down" and "bottomup," with all participating in care of the cardiac surgical patients assuring infection control initiatives were performed.

Active vigilance of outcomes and events our patients experience is the cornerstone of quality improvement initiatives. Much has been learned and reported on reducing surgical-site infections in general and mediastinitis in particular. Virtually all cardiac surgical infection prevention efforts have refined as evidence-based, highly coordinated, multistep, team-based processes. Yet, there must still be individual attention to surgical aseptic details at all times. Awareness of each institutions' microbiologic pathogens and antibiograms can help guide local considerations for improved adaptive antibiotic prophylaxis in collaboration with infection control and infectious disease colleagues.

An important observation by the authors is the relatively flat mediastinitis rate over the last 2 decades. ${ }^{1-3}$ It is remarkable to achieve the low mediastinitis rate of $0.78 \%$ reported here despite significant presence in this VA cohort of these declining-order contributors to mediastinitis: end-stage renal disease, congestive heart failure, diabetes mellitus, chronic kidney disease, and chronic obstructive pulmonary disease.
It's worth restating that this system-wide initiative truly benefitted patients at each site, as there was no significant variation of these excellent results across the 83-hospital system.

"Keep the lights on" deep sternal wound events and recognize the shifting pathogens with Methicillin-sensitive $S$ aureus now dominant and Gram (-) second in the era of enhanced MRSA awareness and prophylaxis. The goal of $0 \%$ mediastinitis remains for all cardiac surgery. Yet, like a top quarkobserving it is difficult and the event fleeting. With consistently reported excellent results plateaued $<1 \%$ for mediastinitis, particularly with comorbidities of current patients undergoing coronary artery bypass, mediastinitis "neverevent" status as stipulated by The Centers for Medicare \& Medicaid Services on January 31, 2008, warrants revisiting.

\section{References}

1. Wojnarski CM, Elgudin Y, Rubelowsky JJ, Wilson BM, Donskey CJ, Cmolik BL. Emerging trends in mediastinitis: National Veterans Health Administration experience with methicillin-resistant Staphylococcus aureus prevention. J Thorac Cardiovasc Surg. 2021;162:1125-30.e1

2. Eklund AM, Lyytikäinen O, Klemets P, Huotari K, Anttila V-J, Werkkala KA, et al. Mediastinitis after more than 10,000 cardiac surgical procedures. Ann Thorac Surg. 2006;82:1784-9

3. Gummert JF, Barten MJ, Hans C, Kluge M, Doll N, Walther T, et al. Mediastinitis and cardiac surgery - an updated risk factor analysis in 10,373 consecutive adult patients. Thorac Cardiovasc Surg. 2002;50:87-91.

\section{Commentary: Eliminating mediastinitis in Veterans Affairs patients - the American Association for Thoracic Surgery guidelines to the rescue}

\section{Harold L. Lazar, MD}

In this edition of the Journal, Wojnarski and colleauges ${ }^{1}$ report the results of their review of the Veterans Affairs

\footnotetext{
From the Division of Cardiac Surgery, Boston University School of Medicine, Boston, Mass.

Disclosures: Author has nothing to disclose with regard to commercial support. Received for publication March 23, 2020; revisions received March 23, 2020; accepted for publication March 24, 2020; available ahead of print April 6, 2020. Address for reprints: Harold L. Lazar, MD, 80 East Concord St, Boston, MA 02118 (E-mail: harold.1.lazar@gmail.com).

J Thorac Cardiovasc Surg 2021;162:1133-5

$0022-5223 / \$ 36.00$

Copyright (C) 2020 by The American Association for Thoracic Surgery

http://dx.doi.org/10.1016/j.jtcvs.2020.03.082
}

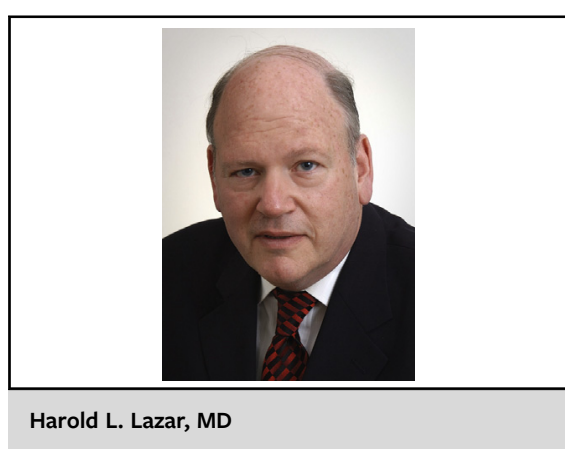

CENTRAL MESSAGE

The AATS guidelines for the prevention and treatment of sternal wound infections should be instituted in all VA centers to eliminate mediastinitis. 